\title{
Women Empowerment in Promoting Ubud as Culinary Destination in Bali
}

\author{
Putu Diah Sastri Pitanatri \\ Lecturer, Department of Hospitality. \\ Sekolah Tinggi Pariwisata Nusa Dua, \\ Bali. Indonesia
}

\begin{abstract}
The development of cultural tourism in Ubud has contributed to the rise of its image as a culinary destination. Surprisingly the ascent of this new image was mainly reinforced by women's role in practicing local culinary entrepreneurship. Even it is acknowledged that culture is a dynamic entity, Balinese women gets very rare exposure in the culinary world as it is commonly known mastered by men.On the other hand, culinary tourism has now taken a major part on many tourist destinations. As an emerging trend, culinary tourism faces the fears the world is surrendering to: McDonaldization and cultural homogenization. With this emerging trend, Ubud's cooking culture and tastes, owns a major potential in promoting the destination. However, as a part of culture local culinary in Ubud is rarely being studied or visible to the academic literatures. Becoming fertile terrain for researches that explore the discipline of cultural tourism, very little research also has been carried out into gender dimension in culinary tourism in Ubud. This paper is a first attempt to unpack women's role in promoting Ubud's image as an emerging culinary destination. Using qualitative method, the paper explores women who have not only succeeded in lifting local culinary as traveller's preferences but also in opening up job opportunities in rural areas. The data presented in this article was collected through observation and in depth interviews of four leading Ubud women who has run successful local culinary outlets or restaurants offering local dishes. The four women surveyed are the owner of Kedewatan Chicken Rice (Nasi Ayam Kedewatan) Ibu Mangku, the owner of the infamous suckling pig in Ubud Ibu Oka, the owner of Bebek Bengil Agung Raka Sueni and the owner of Paon Bali cooking class Ibu Puspawati. Combining literature reviews and data obtained through observation and in depth interviews, this paper aims to provide an overview of the potential of culinary tourism to contribute to the gender equality. The result of this structured evaluation shows that one of the main key elements that played an important role to Ubud's success, as culinary destination is women empowerment. By understanding what and how known restaurants and local talents like Ibu Oka, Ibu Mangku, Bebek Bengil and Paon Bali are achieving their success, food can certainly become a large contribution to sustaining cultural heritage as well as a stepping point to Balinese women empowerment
\end{abstract}

Keywords: cultural tourism, local culinary, destination, gender equity, women empowerment

\section{INTRODUCTION}

For all the negative impacts tourism is blamed for (environmental degradation, cultural exploitation and economic dependence), the empowerment of women is one of the industry's most consistent and creditable positive influences. Granted, many of the most common jobs for women in tourism are low-skilled, lowpaying positions that may actually reinforce existing gender stereotypes. But, when approached with cultural sensitivity and commitment to the community, responsible tourism can provide opportunities beyond some women's wildest dreams.

In Ubud, women are no longer viewed as $2^{\text {nd }}$-class citizens. Commonly marginalized to very limited activities and privileges, fortunately the rise of culinary tourism impacted to gender's equity in Ubud. Women of Ubud are not "just housewives"; in fact some of them have become the most successful entrepreneurs of Ubud.

To date, women empowerment has dominated discussions at local and global scales. Development organizations are continuously translating issues of women empowerment into their practices seeking for more efficient strategies to achieve women empowerment. As the fastest growing industry, tourism indeed has shown potential in not only contributing to but also supporting women empowerment. UNWTO (2010) [1] for example, reveals that women make $60-70 \%$ of the total tourism workforce. Ong (2009) [2] also clearly reveals how tourism, with the embedded element of social entrepreneurship, can perfectly work as the KEY to unlock doors for women. From the above examples, cannot be denied that tourism especially community based and rural tourism has created chances and opportunities for women empowerment. In Ubud this empowerment is supported by the development of culture tourism, aligned with the changes of tourist's motivation visiting this destination.

In earlier days, people tend to visit Ubud to praise for it's visual arts, performing arts and museums. Currently, local culinary has also become one of the reason travellers are visiting this destination. The rise of young travellers who are keen to try something new, distinctively differ from their origins has created a new trend: culinary tourism. According to Besseire (1998) [3], People interested in travelling for gastronomic motivations were increasing gradually. "Culinary Tourism" was a term first suggested in 1998 (Long, 2002) [4]. The term expressed the notion of tourists' experiencing culture of a certain destination through food. 
Culinary or food tourism was one constituent of a tourism strategy dedicated to making the best use of scarce resources in an approach for its creativity and adaptability, made necessary by the lack of conventional natural and cultural tourism assets (Teo \& Chang, 2000) [5]. As an alternative tourism, culinary tourism may become option to several destinations lack of the conventional "sun, sea, and sand". Unlike many other travel activities and attractions, destination's gastronomy was usually available year-round, any time of day and in any weather (Richards, 2002) [6].

Kivela and Crotts (2005) [7] identified that gastronomy was inextricably linked to the destination and the destination's image; maybe multidimensional forms which were clearly understood as yet. Food and beverage could be itself an attraction in a destination, such as Chilli Festival in Singapore food festival, Taste of Chicago, Wine tour in Europe, and Chocolate festival in Suffern, New York, and so on. In these cases, foods either constitute an event attraction or act as the gastronomic part of the attractions in destinations. In other words, the gastronomic experience could become a major, or one of major motivations, for travel (Quan \& Wang, 2004) [8]. As it can be seen, for some areas, gastronomy has become an important attraction and is influential to their development. Therefore, the issues related to the development of culinary tourism especially related to gender's equality are worth of more attention and contribution in the future.

\section{METHOD}

The study is based on in depth interviews, a method appropriate for inductively examining people's views regarding a phenomenon (Berg 2001). The interview questions were grouped in 3 sets. The respondents were asked to describe (1) the characteristic of their product, (2) their challenges and obstacle in developing the local food general, and (3) the relevant tourism changes that directly affect their warung's. The interviews were conducted in December 2015 until February 2016 to notably successful entrepreneur in Ubud. Ibu Mangku with her Chicken rice of Kedewatan, Ibu Oka with Babi Guling Ibu Oka, Ibu Raka Sueni with Bebek Bengil and Ibu Puspa with her Paon Bali Cooking Class.

By qualitative approach, each question was carefully examined with relevant theories and research. The approach of this paper is to look into efforts of successful woman entrepreneurs who does not that create a distinctive local food product of Ubud, but also fosters women empowerment within their areas. This study on woman empowerment may suggest on how local-Balinese food become more sustainable in rapid tourism development of Ubud.

\section{FINDINGS AND DISSCUSIONS}

\section{a. Development of Ubud as a Local Culinary Destination}

In the early 1990s, Ubud has begun creating attention through its variety of local cuisine enjoyed by tourists, both domestic and international tourists. Similar to any destination, local food was always popular to the local, but not as tourist consumption. On the other hand, scholars, anthropologies and researcher mostly associate Ubud to the art world. Local food was not popular within the cultural treasures of Ubud.

Even so, Miguel Covarrubias in his book The Island of Bali (1937) [9] , did a little research of Balinese food in Ubud. As a painter and scholar of anthropology, Covarrubias lived in Bali for three years in the early 1930s. Not only introducing the island from the perspective of social structure, history and geography, Covarrubias also indirectly promote Bali through the captivating picture of Balinese art, music and drama. In one of the sub-chapter on the daily life of the people of Bali, Covarubias wrote his opinion on traditional Balinese dishes.

Balinese food is difficult to the Westerners tongue. The food is so spicy even for me, a Mexican who grew up with chili, tears and sweat. However, after the first shock, we then become familiar to the taste of Bali. We evolved into Balinese cooking and immediately began to try this strange mix of spices

(Covarrubias, 2014: 107).

Seeing this statement, it appears that traditional Balinese cuisine has a distinct taste but still can be acceptable to the "western tongue". In the process, traditional culinary is supported by the increasing demand of international tourists who seeks authenticity though their cultural travel to Ubud. Ubud transform to place to get an authentic experience of local culinary.

Ubud culinary development actually started with the opening of several local restaurants that are not only private consumption but also tourists both domestic and foreign. Ibu Mangku, Ibu Oka, Ibu Raka Sweni and Ibu Puspa are the four pioneers who 
strengthened the existence of Ubud as local culinary destinations. Their existence was actually supported by the number of millennia travellers who came to Ubud. These types of travellers are keen to share local food they experience in Ubud. Not only visual, videos are also being uploaded in YouTube. To date almost 29.500 results were found when "Ubud Food" is being searched.

Nasi Ayam Kedewatan Ibu Mangku (Kedewatan chicken rice) for example, become popular after many tourists writes reviews on TripAdvisor and personal blogs. At the very beginning, this small warung (local restaurant) is a stopover for suppliers who transport fruit, vegetables and other crops to Denpasar. Guides who work at Ayung River rafting in the eraly 90ties are also a huge fan of Ibu Mangku and widely introduce her menu to their guest. After few resorts in Sayan open, guides also start to recommend this chicken rice to tourists. Nasi Ayam Kedewatan also very popular among domestic tourists who visit Ubud and seeking for "halal" food.

Unlike Ibu Mangku, Babi Guling (suckling pig) of Ibu Oka, became popular to the western world after one of the infamous TMC's food program "No Reservation" aired in 2006. As mentioned by Putra (2014: 83) [10] the popularity of Ibu Oka become magnet that attracts celebrity like Anthony Bourdain, to come to Ubud and make a feature story about Indonesian and Balinese dishes. This program has made Balinese suckling pig $\mathrm{Bu}$ Oka as the focus of attention.

While visiting the diner, Anthony Bourdin even mention, "this mouth- watering Babi Guling, or suckling pig, was the best that I've ever had". The endorsement went viral and has increased the popularity Bu Oka Babi Guling among tourists and travellers. After the feature story, number of tourists to this warung increases dramatically. To cater her hungry customers, Ibu Oka has to open 2 branches. Not only Bourdain, Rick Stein and Bobby Chin also visited Babi Guling Ibu Oka during their visit to Ubud. It is clear enough to see that when western culinary stars say it's delicious, the world listens

Expatriates who lived in Ubud are also promoting Balinese local culinary through books. Ubud who was once only existed in museums, arts and culture books, now has begun to appear in the cookbooks like Bali Unveiled: The Secrets of Balinese Cuisine (2004) by Chef Heinz von Holzen and Bali: Food of My Island (2011) by Janet de Nefee. These cookbooks notably gave new dimensions of local Balinese food. Tourist and traveller who visit Ubud can now enjoy food that was once known "tribal" to the western world.
Considering the various developments it appears that local culinary has become one of the magnet for tourist to visit Ubud. Ubud which was only known as a for cultural tourism destination now is supported by it's new brand as a local culinary tourism destinations. This reinforces the existence of Ubud as a destination for cultural tourism in Bali.

\section{b. Woman's Role in Promoting Ubud as Culinary Destination in Bali}

Women have played an "invisible" role for a long period of time in the tourism development, as they have been perceived as assistants, wives and mothers, and as generally subservient to the dominant economic work of men (O'Toole \& Macgarvey 2003 [10]). Nowadays, local economies are beginning to include the female labor force on the local agenda for economic and tourism development. This development have support women to enhance entrepreneurship, alongside schemes to finance and foster the creation and growth of women's businesses tourism areas, thus changing women's role and giving them an opportunity to take part in business activities largely similar to those traditionally performed by them at home. Various work has sought to examine women entrepreneurs (Baygan 2000; Bruni et al. 2004; Smith-Hunter \& Boyd 2004) and many studies have discussed personal characteristics, industry/business choices, and barriers to success (Greenberger \& O’Neil 1993) [11] as well as theoretical issues in an attempt to explain why women do the jobs they do (Little 1991).

In Ubud, the developments of culinary tourism are inseparable from women's role. From time, there are many Balinese women who participated in promoting Ubud as a culinary destination. Some entrepreneurs however, has strongly contributed in the development of new attributes of Ubud. The determination of these women interviewed in this study pursed with the following criteria:

1. Represent the initiators and owners of Balinese culinary business in Ubud

2. Intensely promote culinary varieties Ubud, not only for the local society but also to domestic and foreign tourists,

3. National and international media exposure, online and offline. 
4. Number of awards received in the national and international levels and,

5. Good ratings on TripAdvisor; at least once awarded as TripAdvisor's Travellers Choice Awards.

Of the five criteria above, there are four figures that reinforce Ubud's image as a culinary destination. Sang Ayu Mangku, the owner of a Nasi Ayam Ibu Mangku Kedewatan, Anak Agung Raka Sinar, the owner Oka Babi Guling Bu Oka, Anak Agung Raka Sueni, the owner of Bebek Bengil restaurant and Ni Luh Made Puspawati, the owner Paon Bali cooking class.

These women are not only good in cooking but most importantly; they have strategies and capabilities in raising their businesses while making barriers irrelevant. Persistence, these culinary "Srikandi" of Ubud forges their efforts to introduce local foods Bali to national and international tourists. They are also an example that contribution of women in the development of tourism in Bali is immense. Outlining their efforts, there are four main focuses of which these woman are proficient; quality assurance, customer's satisfaction, managerial efforts, and promotional activities.
From the table 1, it is clear enough to see that these local stalls (warung) are maintaining their quality though adoption and adaptation of taste and hygiene standards. Adopt is absorbing the method and style of traditional cooking and expressing it in a way that remains unique and authentically Bali. On the other hand, adaptation on quality control of traditional Balinese food products is also mandatory. The reason is simply because beside of its ingredients, cooking techniques of the common "Balinese traditional Chefs" are the weakness of Balinese cuisine. From preparation to serving table, most are usually processed with bare hands. On many part of the island, hygiene and sanitation standards are still the main issue of Balinese cuisine.

\section{Table 1. Woman's Role in Promoting Culinary Tourism in Ubud}

\begin{tabular}{|c|c|c|c|c|}
\hline & $\begin{array}{l}\text { Sang Ayu Mangku } \\
\text { (Nasi Ayam } \\
\text { Kedewatan Ibu } \\
\text { mangku) }\end{array}$ & $\begin{array}{l}\text { AA Raka Sinar (Babi } \\
\text { Guling Bu Oka) }\end{array}$ & $\begin{array}{c}\text { AA Raka Sueni (Bebek } \\
\text { Bengil) }\end{array}$ & $\begin{array}{c}\text { Ni Luh Puspawati (Paon } \\
\text { Bali) }\end{array}$ \\
\hline Quality & $\begin{aligned} & \text { Flavor consistency } \\
& \text { - Menu consistency } \\
& \text { - Adaptation on spicy } \\
& \text { - ingredients (basa } \\
& \text { pelalah) }\end{aligned}$ & $\begin{array}{l}\text { Consistency in } \\
\text { - } \text { process and } \\
\text { seasoning } \\
\text { measurement } \\
\text { Adaptation on spicy } \\
\text { - } \begin{array}{l}\text { ingredients (basa } \\
\text { pelalah }\end{array} \\
\end{array}$ & $\begin{array}{l}\text { Research and quality } \\
\text { - improvement } \\
\text { Menu varieties } \\
\text { - } \text { Adaptation on process } \\
\text { - }\end{array}$ & $\begin{array}{l}\text { Dharma Caruban } \\
\text { - (Balinese cookbook) } \\
\text { Traditional recipes } \\
\text { - Adaptation on spicy } \\
\text { - ingredients (basa } \\
\text { pelalah }\end{array}$ \\
\hline $\begin{array}{l}\text { Customer } \\
\text { Satisfaction }\end{array}$ & $\begin{array}{l}\text { Hygiene and } \\
\text { - sanitation standards } \\
\text { Presentation } \\
\text { - standards } \\
\text { Balinese atmosphere } \\
\text { - in each warung's } \\
\text { Family business } \\
\text { - Employee training } \\
\text { - Employee benefit } \\
\text { - }\end{array}$ & $\begin{array}{l}\text { Hygiene and } \\
\text { - sanitation standards } \\
\text { Balinese atmosphere } \\
\text { - in each warung's } \\
\\
\text { Family business } \\
\text { - Employee benefit in } \\
\text { - time flexibility }\end{array}$ & $\begin{array}{l}\text { Hygiene and sanitation } \\
\text { - standards } \\
\text { Creativity and innovation } \\
\text { - Balinese atmosphere in } \\
\text { - each warung's } \\
\text { Supporting facilities (wifi) } \\
\text { - Family business supported } \\
\text { - by appointed managerial } \\
\text { team } \\
\text { - Employee training }\end{array}$ & $\begin{array}{l}\text { Hygiene and sanitation } \\
\text { - standards } \\
\text { The "experience" } \\
\text { - element } \\
\\
\text { Family business } \\
\text { - Part time employees, } \\
\text { - local surrounding } \\
\text { community }\end{array}$ \\
\hline $\begin{array}{l}\text { Promotional } \\
\text { Activities }\end{array}$ & $\begin{aligned} & \text { National media } \\
& \text { - exposure } \\
& \text { - Food blogger } \\
& \text { - Social Media }\end{aligned}$ & $\begin{array}{l}\text { Travel channel } \\
\text { - TripAdvisor } \\
\text { - Food blogger }\end{array}$ & $\begin{array}{l}\text { Media exposure } \\
\text { - TripAdvisor } \\
\text { - Food blogger } \\
\text { - Own Website } \\
\end{array}$ & $\begin{array}{l}\text { TripAdvisor } \\
\text { - International media } \\
\text { - exposure } \\
\text { Food blogger } \\
\end{array}$ \\
\hline
\end{tabular}


As of managing the establishment, family and relatives are still their upmost preference. Bu Oka for example, has composed SOP's to all her sons, daughters and relatives. Even it is being managed traditionally, each of these family members have to obey the Bu Oka's standards professionally. As no ingredients are imported, local farmers are also support the warung though local produce.

In regards to promoting their warung, none of these establishments has put a large investment of advertising and promotional items. Their customers who posted their experiences through TripAdvisor, personal blogs and social media mostly made their promotion. These unpaid, effective recommendations are one of the most important key elements in sustaining their business to date.

Based on the interviews it can be said that for women of Ubud who participated in promoting culinary tourism have increased their self-esteem and status within their community through tourism. These women are more actively involved in decision-making in their community and have taken on new leadership roles. Culinary have provided them an opportunity to develop multidimensional empowerment at both the individual and collective levels.

\section{c. Authenticity of Local Food: Extinct or Extant}

Despite its success, the emerging trends of culinary tourism in Ubud also raised debates. Some said that Ubud is now too overcrowded with non-local restaurants, which served endless varieties of non-local food. Others also said that local culinary has lost its authenticity or becoming too touristic. However during interviews for this research, none of these local entrepreneurs consider themselves change for the sake of tourism.

Existence between elements of culture and tourism in Bali has always been an endless discussion. Tourism as the bread and breath of Bali is often considered as the main cause of cultural degradation. Socio-cultural change in the community structure, and touristic culture, impacted on the quality of arts and the way people live in in Bali. To many researchers, culture and tourism cannot be coexisted.

Picard 1996 [13] strictly mentions that cultural tourism itself is bringing Balinese into two different poles. At one side of the pole, it has given Balinese the authority to maintain and do preservation of traditions, customs and culture. On the other side of the pole culture is exactly what is being "sold" to international community through tourism. Commodification and commercialization then became synonymous with the development of tourism in an area. The assumption is; if tourism is growing rapidly, it is almost certain culture at the destination will be marginalized, and the younger generation will lose its identity by following the culture that brought tourists.

However, in seeing many changes in Balinese society, we should realize that change is inevitable, even it is something expected by people. As said by Warren $\mathrm{J}$ Samuel (1991) in Pitana (2006) [14] the elements of culture are subject to continuous social reconstruction. As a matter of fact, Balinese do not put tourism and culture in a linear and one-way cause-and-effect relationship. Instead, The "tree analogy" is subscribed for this.

Figure 1.The Tree Analogy by Pitana (2006); Picard (1996), Geriya (1991), McKean (1978). Adapted and visualized by Pitanatri (2015)

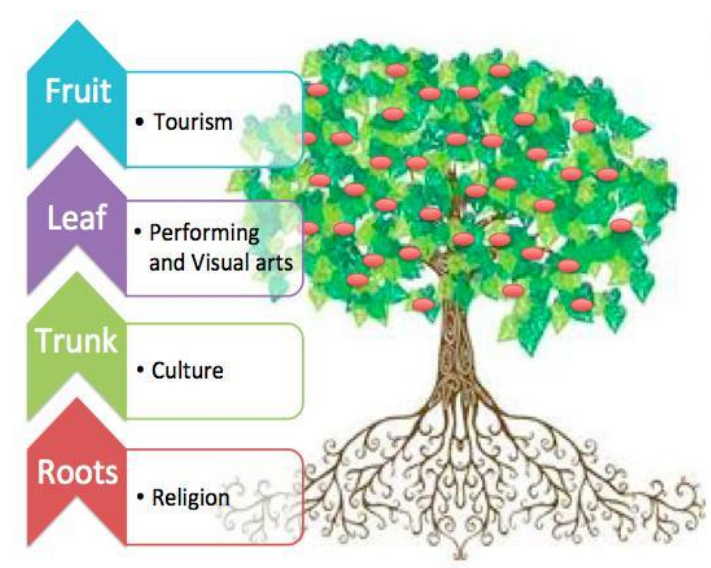

In the tree analogy as the expansion of cultural tourism concept in Bali, the roots of the tree symbolize Hinduism. The strong trunk represents culture in general, both tangible and intangible. The lush and beautiful leaves are the representation of Balinese art in the form of visual arts and performing arts. Tourism is the flowers and fruits that can be "harvested" so it can later be allocated for the welfare of the local community. The produce of the tree in the form of flowers and fruit are what can be "sold", but the revenue generated from these sales should be invested back into the tree. When the roots and trunk of the tree is strong then it would be able to produce healthy leaves with sweet fruit and blooming flowers. By applying the tree analogy as the representation of culture tourism in Bali; religion, culture, arts and tourism will no longer be a paradox. Each part will work together to strengthen each other, and the people of Bali have proven to be able to balance the paradox of tourism through the tree analogy.

Promoting local cuisine can be defined as one of the utmost important aspect of culture tourism. Tourism will not only sustain Balinese food existence but also give chances to the local community to get benefit from 
tourism; contributing the revenues back to nurture the roots of culture tourism. For a local cuisine to become a popular attraction in its own right, it has to be filtered through tourism-oriented culinary establishments; only after they are in some ways, and to some degree, transformed. However, the manner of their transformation cannot be simply represented on some unidirectional and un-dimensional scale (Cohen dan Avieli 2004:6) [15].

These transformations make local food in a slightly different dimension and are often customized by the tastes of tourists, without changing its authenticity. Not all aspects of the local culinary are relevant to maintain food "authenticity". Replacing some of the material that are more acceptable to tourists and the use of modern technology to improve sanitary conditions is also a part of transformation. Peking duck in Beijing, for example, is very popular cooked by an electric oven instead of a conventional oven. Changes were also seen in traditional Thai cuisine that has been known worldwide such as Tom Yam. Tom Yam is recreated so that it can be enjoyed internationally. Korean Kimchi is also recreated to reduce the acidic smell. These changes can be seen as a dynamic form of culture, which continues to develop without losing the essence and the local taste of place.

\section{CONCLUTIONS AND SUGGESTIONS}

Women have played an 'invisible' role for a long period of time in the tourism development of Ubud, as they have been perceived as helpmates, wives and mothers, and as generally subservient to the dominant economic work of men. Nowadays, the development of tourism in Ubud is beginning to include the female on the local agenda especially for culinary tourism development. The changing of women's role are giving them an opportunity to take part in business activities largely similar to those traditionally performed by them at home.

Following the success of Ubud's famous warung's like, Ibu Mangku Chicken Rice of Kedewatan, Babi Guling Ibu Oka, Bebek Bengil and Paon Bali cooking class, food tourism is labor intensive and creates jobs while also stimulating agriculture, and they generally do not require any major new investment. Food can contribute to regional attractiveness, sustaining the local environment and cultural heritage as well as strengthening local identities and sense of community. When the food of Ubud enjoys an equal success like other cultural interests, Ubud will be known as a destination with a complete cultural discovery.

Food tourism is an up-and-coming, blossoming niche both in the tourist market and for academic research. Clearly there is a newfound appreciation and demand for high quality food with a legacy, a history, and a story, and many are willing to travel far and wide to experience this. Regardless, regional markets have potential to capitalize on this new commodity, and through careful marketing and planning can bolster the economies of small farmers and other purveyors as well as areas with sagging economies.

\section{REFERENCES}

[1] UNWTO. Global Report on Women in Tourism 2010: Preliminary Findings. World Tourism Organization (UNWTO) and the United Nations Entity for Gender Equality and The Employment of Women (UN Women)

[2] Ong, S.T., 2009. Women Empowerment through TourismFrom Social Entrepreneurship Perspective. Accessed October 4, 2010 at http://edepot.wur.nl/11305

[3] Bessière, Jacinthe. 1998. Local Development and Heritage: Traditional Food and Cuisine as Tourist Attractions in Rural Areas. European Society for Rural Sociology Sosiologia Ruralis Vol 38 (1) pg. 21-34.

[4] Long, L.M. 2003. Culinary Tourism and The Emergence pf Appalachian Cuisine: Exploring the "foodscape" of Asheville, NC.

North Carolina Folklore Journal, 57(1) pg. 4-19.

[5] Teo, P., \& Chang, T. C. 2000. Singapore: Tourism development in a planned context. In C. M. Hall, \& S. Page (Eds.), Tourism in South and Southeast Asia: Issues and cases (pp. 117-28). Oxford: Butterworth-Heinemann.

[6] Richards, G. 2002. Gastronomy: An Essential Ingredient in Tourism Production and Consumption? Dalam A. M. Hjalager dan G. Richards (Ed.), Tourism and Gastronomy pg. 3-20. London: Routledge.

[7] Kivela, J. dan Crotts, J. 2006. Tourism and Gastronomy: Gastronomy's Influence on How Tourists Experience A Destination. Journal of Hospitality and Tourism Research, Vol. 30(3) pg. 354-377.

[8] Quan, S. dan Wang, N. 2004. Towards a Structural Model of The Tourist Experience: An Illustration From Food Experiences in Tourism.

Journal of Tourism Management, Vol 25(3) pg. 297-305.

[9] Covarrubias, Miguel. 2014. Pulau Bali: Temuan yang Menakjubkan. Udayana University Press

[10] O'Toole, K. and Macgarvey, A. (2003). "Rural women and local economic development in south-west Victoria". Journal of Rural Studies, 19: 173- 186.

[11] Putra, I Nyoman Darma. 2014. Empat Srikandi Kuliner Bali: Peran Perempuan Dalam Pembangunan Pariwisata Berkelanjutan. Jurnal Master Pariwisata JUMPA Vol 1(1) pg. 65-94.

[12] Greenberger, E. \& O’Neil, R. 1993. Spouse, Parent, Worker: Role Commitments and Role-Related Experiences in The Construction of Adults' Well-Being, Developmental Psychology, vol. 29, no. 2, pp. 181- 197.

[13] Picard, Michel. 1996. Bali: Cultural tourism and touristic culture. Singapore: Archipelago Press.

[14] Pitana, I Gde. 2006. Kepariwisataan Bali dalam Wacana Otonomi Daerah. Jakarta: Puslitbang Kepariwisataan, Kementerian Kebudayaan dan Pariwisata.

[15] Pitanatri, Diah. 2015. Adopt, Adapt, "Adep": Promoting Bali As A Cultural And Culinary Destination. Proceeding Bali Tourism Forum International 2015.

[16] Cohen, E., dan Avieli, N. 2004. Food in Tourism: Attraction and Ompediment. Annals of Tourism Research, Vol 31(4) pg. 597-617. 